\title{
15
}

\section{Afterword: Disasters, Regenerations and Ambiguities}

\section{Disasters}

The battle between the Georges River oyster farmers and the cashedup waterfront block owners at Sylvania continued across the 1970s. The waterfront landowners were represented by the Georges River Oyster Lease Protest Association, enthusiastically supported by the St George and Sutherland Shire Leader. Then disaster struck, in July 1978, with 2,000 people across Australia developing acute gastroenteritis after eating Georges River oysters. ${ }^{1}$ Contributing to the resulting panic, and without any proof, the Leader suggested that the poisoning was caused through contamination of oysters by parvovirus, a virus rarely found in humans (and in whom it has very different symptoms than those of gastroenteritis) but with a canine variant with which many readers would have been familiar. ${ }^{2}$

1 'Oyster Ban "Disaster for Farmers"', St George and Sutherland Shire Leader (hereafter Leader), 19 July 1978, 5; 'Oyster Famers to Meet Over Freeze on Sales', Leader, 2 August 1978, 11; 'Oyster Farmers Start Afresh', Leader, 23 August 1978, 9; 'Safeguards for Oysters', Leader, 6 September 1978, 2. 2 “'Ghost” Ban on Oysters: "No Evidence”, Leader, 4 October 1978, 1; 'Oyster Firm Shells Out to Prove Point', Leader, 11 October 1978, 15. 
It took 16 months, to October 1979, until the results of research into the contamination were published in the Medical Journal of Australia. The authors, Murphy, Grohmann and Christopher, with others, found that the harmful contaminant in the oysters had indeed been a virus, not bacteria, but that it had not been parvovirus. Their bacteriological tests showed that, while 'some batches of oysters were contaminated by sewage', it was not any bacterial contaminant in the oysters that had been passed on to the people who became ill after eating the oysters. Instead, what had affected them had been Norwalk virus, 'a known cause of acute nonbacterial gastroenteritis' that 'has not been identified previously outside the United States of America and has not been linked to food-borne gastroenteritis before'. ${ }^{3}$

This result was a surprise for people who had assumed it was the sewage contamination that had caused the problems, although it did little to dispel the general disquiet. In response, Georges River oyster farmers withdrew their oysters from sale and the Minister for Fisheries introduced 'fishing closure' restrictions under the Fisheries and Oyster Farms Act 1935 to prohibit the taking of oysters from the estuary. Sites were chosen further into Botany Bay at, for example, Weeney Bay and Quibray Bay on the eastern side of Towra Point, where oysters could be held before marketing to allow cleansing from contaminants by natural elimination. In addition, many oyster farmers began the installation of expensive purification equipment. ${ }^{4}$

But the damage had been done. After two decades of troubling headlines about sewage pollution, and despite strenuous efforts by oyster farmers to repair the image of their product, consumers responded by turning away from oysters grown in the river. There were faltering restarts but the industry was then afflicted by further troubles: first by poisonings of the oysters by TBT (an ingredient in anti-fouling paint put onto watercraft prohibited in many countries and eventually in New South Wales); second, by the aggressive impacts of the introduced Pacific oyster; and, finally, in 1994, by QX disease, a parasite that killed up to 90 per cent of all the rock oysters in the Georges River. ${ }^{5}$ By 2000, oyster farming

3 Murphy et al., 'An Australia-Wide Outbreak', 329.

4 'Safeguards for Oysters', Leader, 6 September 1978, 2; 'Oysters Get Clean-Up', Leader, 8 November 1978, 2; 'Breakthrough Claim in Clean Oyster Study', Leader, 15 November 1978, 9; 'Oyster Growers "Saved": Mammoth Job Ahead after Lifting of Four-Month State Ban', Leader, 22 November 1978, 2; Derwent, interview.

5 Nell, 'The History of Oyster Farming', 20. 
closed down on the Georges River almost entirely, continuing only in one isolated leasehold, with Sydney rock oyster production now continuing in coastal locations to the north and south of Sydney. ${ }^{6}$

The impact on members of the extended oyster farming families among Georges River residents has continued to be distressing. Some oyster farmers, like Laurie Derwent, had left the industry before the problems from 1978 emerged. He retrained in environmental studies and worked in conservation, administration and legal roles in state government agencies. ${ }^{7}$ Others retired, ${ }^{8}$ but some were simply shattered, forced onto the dole for the first time in their lives and left with few possibilities for productive work. ${ }^{9}$

\section{Regenerations}

The campaigns of the 1970s built on the work of the 1950s campaigners and carried the new wave of the river lands' regeneration. For all their limitations, their monoculturalism and their localisms, these campaigns halted the rush of local and state governments to solve both sewage and garbage problems by dumping waste into the river or onto the surrounding wetlands. By saving the riverbed, water quality and at least some of the foreshores, these campaigns allowed a breathing space. Some of the new wave of regeneration was led by ideas introduced very directly by these campaigners.

One idea was about recycling as a way to address the unmanageable explosion of garbage. The very first press release of the Lime Kiln Bay Preservation Committee directed Hurstville Council to take up the separation and sorting of solid waste into different types of materials and to seek out ways to use these products fruitfully: 'We just cannot go on forever tipping into our rivers and estuaries. No mangrove area is safe anymore.' Recycling was not being used by any local government in

6 Drake, interview. The only remaining oyster lease on the Georges River, originally developed by Bob Drake, president of the Oyster Farmers Association from 1978, was covered in ABC TV Landline, Sunday 22 June 2020.

7 Derwent, interview.

8 Drake, interview.

9 Knight, interview. 
Australia at that time, but the sustained pressure from campaigners like the Lime Kiln Bay group has led to the situation now where recycling is widespread. ${ }^{10}$

Another of the ideas raised from the beginning of the Lime Kiln Bay campaign was to work with engineers and biologists to better manage household run-off so that water coming into the river was made cleaner. Continued pressure from the Lime Kiln Bay campaigners on Hurstville Council led to the successful development of an artificial wetlands scheme there, which has in turn drawn back the abundance of bird and native animal life as well as expanding the spaces for sociality and picnics along with walking places for local residents and their dogs.

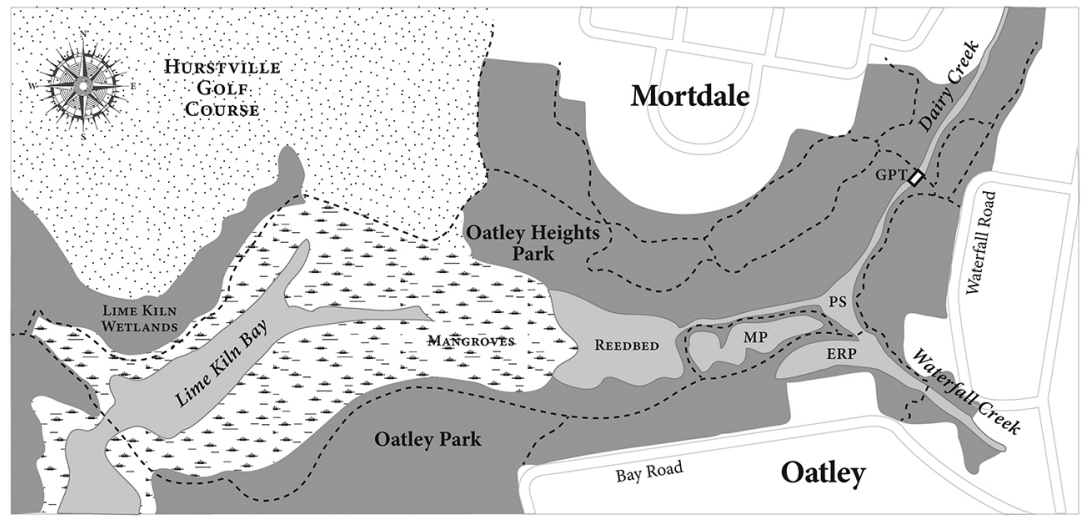

\section{Legend:}

200 metres

GPT Gross Pollutant Trap

MP Macrophyte Pond

PS Primary Sediment Pond

ERP Eastern Ridge Pond

-. - - Walking Track

\section{Map 15.1: Saving Lime Kiln Bay.}

The Lime Kiln Bay Preservation Committee argued for a filtration system to protect the bay from polluting run-off from surrounding suburbs. The result is shown here in the presentday Dairy Creek pollution trap and pond filtration system, eventually built by the state government, to protect Lime Kiln Bay from storm water run-off. Map redrawn for this volume with permission from Mo (2015). Cartography: Sharon Harrup.

10 LKBPC Press Release 1, [December 1973], reported in 'Hands off Lime Kiln Bay, Petition Urges', Leader, 9 January 1974, 11 and 'Study Need Before Bay Reclaimed', Leader, 23 January 1974, [supplement, 10]; 'It's Getting Worse: Mangrove Dumping Protest', St George Pictorial, 9 January 1974, 1 . 


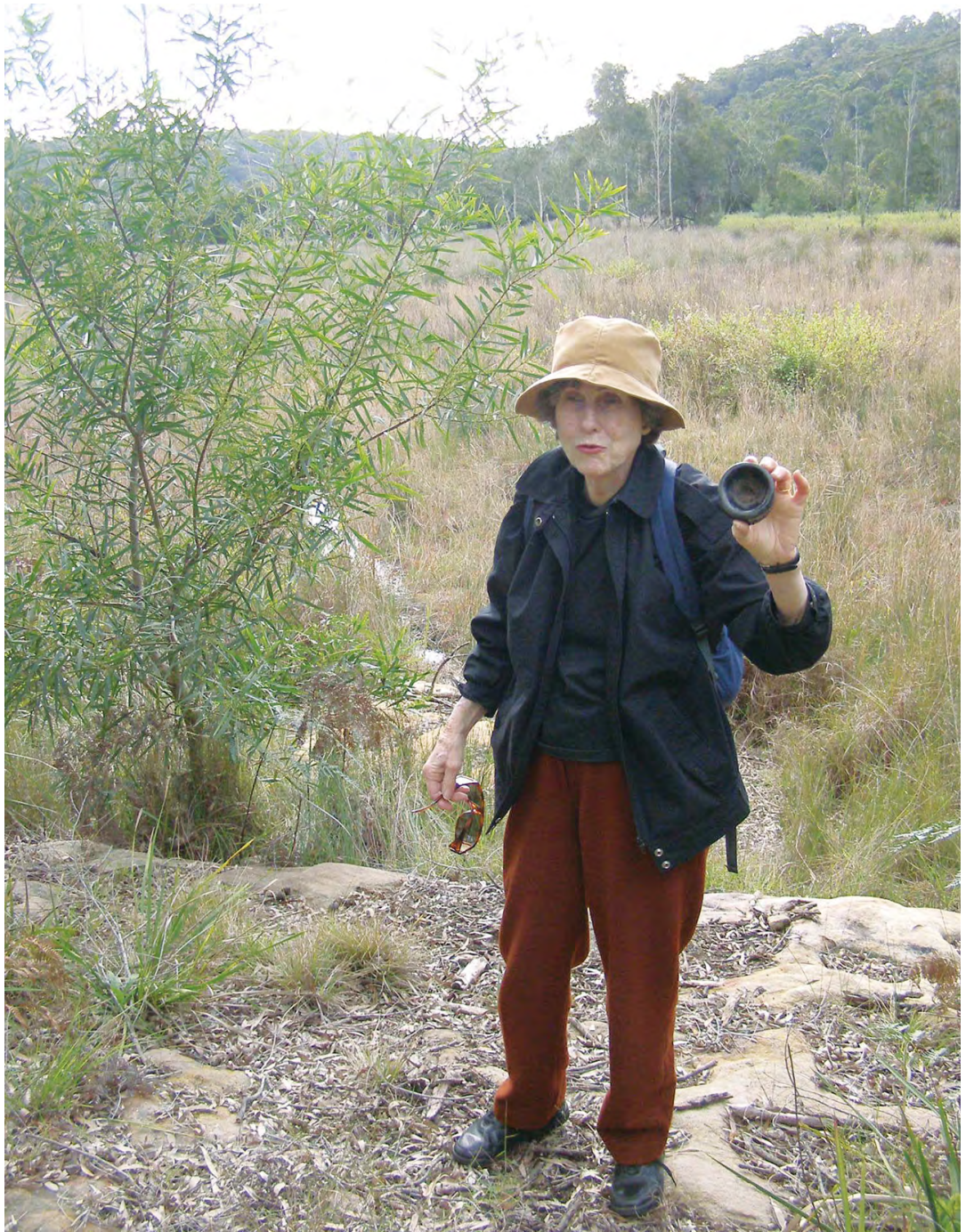

Figure 15.1: Ruth Staples, bank regenerator, 2009.

Ruth Staples continued to be active in bush regeneration along the Georges River until she became unwell in the last year of her life. She is shown here exploring the saltmarsh area on lower Mill Creek (Guragurang). Photographer: Heather Goodall.

Yet another Lime Kiln Bay proposal was that the vegetation on creek and riverbanks should be restored to a healthy state, both aiding in the improvement of water quality and the environment of living creatures in the water and on the foreshores. The method the Lime Kiln Bay campaigners suggested was the Bradley method for bush regeneration, another early strategy that was to prove effective and was widely adopted. 
Although labour intensive, it has demonstrated its value in removing invasive species and fostering regrowth among locally endemic species. Further, because it demands such intensive labour, it has been organised through groups of volunteers, thus offering a new way to practice and expand the sociality that had been so important in earlier uses of the river lands. When funding has been available, councils have managed such regeneration work, but the local volunteer groups have continued whether or not there were paid coordinators available. This has remained a local resident-driven environmental process. ${ }^{11}$

As the local campaigns in the 1970s demonstrated, children were involved along with their parents in the campaign work, dropping off leaflets and stickers, collecting signatures for petitions and spreading the word among school friends. At least some of these younger members of the campaigning families went on to careers in environmentally related professions. ${ }^{12}$ The Georges River blues have, of course, continued, with a recent conflict in 2018 when Hurstville Council and then the Georges River Council sought to sell off the former Oatley Bowling Club site (being part of Myles Dunphy Reserve) for housing development. There was strong local resident protest, including younger members of families who had been involved in earlier protests against reclamation. Only after this local protest did the Department of Planning step in, refusing permission for the sale as there was too little public open space left in the area. ${ }^{13}$

The local municipal and shire councils to which the campaigners became increasingly opposed were themselves divided. At times such divisions aligned with party affiliation, but it was not always so simple. Some leftwing representatives and officers were focused on playing fields, like the Australian Labor Party Hurstville councillor, Alderman Lawrance. There were others, however, considered to be conservatives, at local government and state government level, like Eric Willis, who were very responsive

11 Staples, interview, 27 October 2005; Koffel, interview; David Koffel, notes of a meeting with Hurstville Municipal Council, 28 February 1975, LKBPC Archive; Australian Association of Bush Regenerators, 'The Bradley Method', accessed 21 January 2021, www.aabr.org.au/learn/what-i-bushregeneration/general-principles/the-bradley-method/. Now part of Georges Riverkeeper program, when funding is available, see Salt et al., 'Georges Riverkeeper'. See also Benson and Howell, Taken for Granted.

12 Robert Haworth, from Lime Kiln Bay (Ruth Staples's younger brother); Laurie Derwent and Alexandra Knight (from the Derwent oyster farming families who became active in the Oatley Bay campaign) are examples. Even with less direct involvement in the environmental campaigns, the experience of growing up on a threatened river was motivation for studies in ecology. Saintilan, interview. 13 Laurie Derwent, pers. comm., describing his daughter's participation to protest the sale. 
to emerging environmental ideas and rising pressure from residents. Always there were competing demands - in gentrifying suburbs with very different class and real estate values, and between waterfront landowners and oyster farmers - as well as the persistence of myths and wartime experiences, so it was only to be expected that the councils were unreliable allies. Yet, some officers, like Hunt and Howard in Bankstown, as well as councillors like Gietzelt and Skinner in Sutherland, and Julian Sheen in Hurstville, were able to offer support as the emerging campaigns took shape. Eventually, the Georges River Council's Riverkeeper program was initiated in the 1990s, bringing together many councils in improving the health of the river. ${ }^{14}$ Alongside the campaigners and local government officials and representatives, those who most brought about change were unquestionably the Fisheries Branch biologists Don Francois, W. B. Malcolm and others who gave up their time to engage in what is often called 'outreach' to teach and learn with local people about how best to intervene in damaged, suburban riverine environments. It was this patient interchange over many years that ensured that groups like the Lime Kiln Bay Preservation Committee and the Save Poulton Park Campaign had the information and language needed to power their campaign.

\section{Ambiguities}

The campaigns had consequences that were often different from those that activists had imagined. The river and its foreshore parklands had been more or less saved through their activism, which drew together diverse interest groups from fishers and oyster farmers through to picnickers and birdwatchers through to health professionals and aquatic ecologists. Their campaigns enabled the continuation of the mixed open space of the river and foreshores, with a combination of picnic spaces, playing fields and bushland. The spaces still allowed for socialities, but they were not necessarily the ones expected by the campaigners. The continuing expansion of the population meant that all the quiet market gardens and backwater creeks where non-Anglo groups had gathered for their shared meals, games and ceremonies in earlier years had all been subdivided and sold. Increasingly, as the population aged, the young people for whom the campaigners had wanted to save the bushland or build the playing fields had grown up and moved away.

14 Salt et al., 'Georges Riverkeeper'; Cavanaugh, 'The Aboriginal Riverkeeper Team'. 


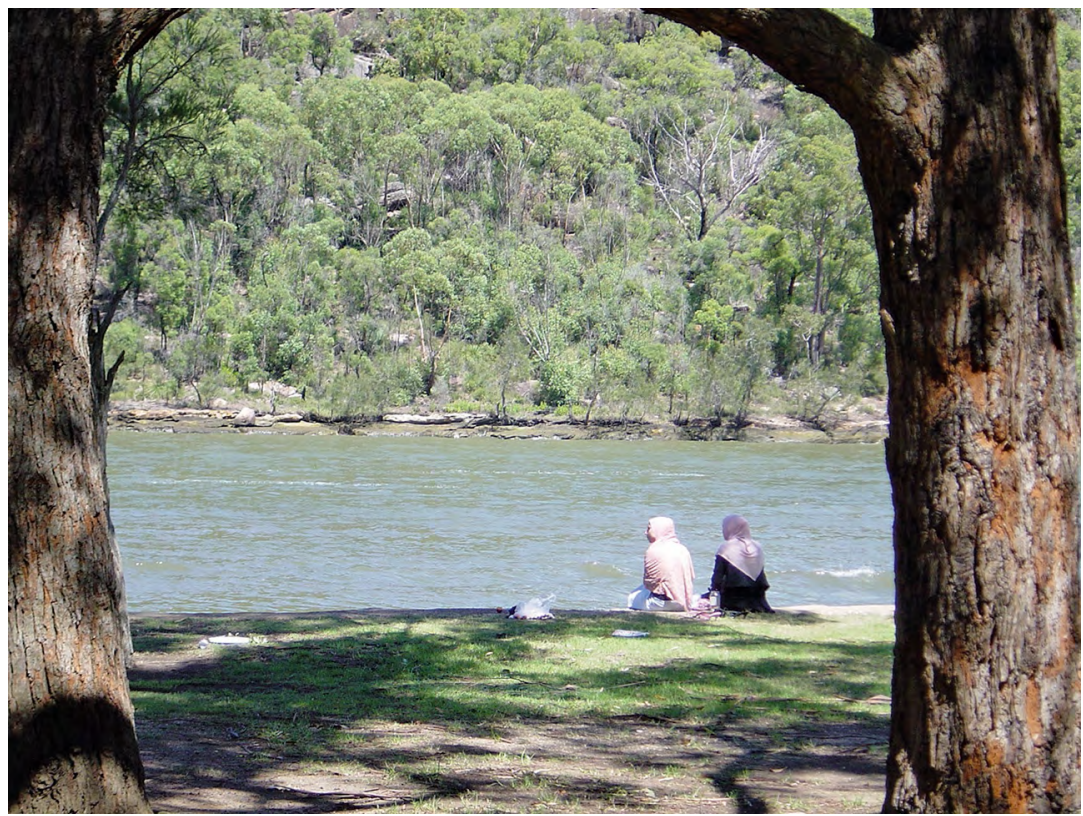

Figure 15.2: Australia Day, Burrawang Reach, Georges River National Park, 2005.

Picnickers at the Georges River National Park include many immigrant families, who come from many different places, including Vietnam and the Middle East. Georges River Arabicspeakers include Christians, Mandaeans and Muslims, such as these women in hijab sitting beside the river. Photographer: Heather Goodall.

Now, in the twenty-first century, there are new immigrants and refugees coming to work in the factories or live in the hostels along the river. Since the 1990s, the people who have come to the parklands and the river to picnic or play sport have not come from old Anglo and Irish families. Instead they have been Vietnamese, Arabic-speaking, Pacific Islander or African families, bringing their old people to remember the homes they had left behind and their children to hear those stories of lost homes or to explore and play games to learn more about their new homes. ${ }^{15}$ In many ways, these new gatherings looked different from the old Sunday school picnics or factory Christmas parties or the earlier shared meals around fires that had created the middens. They might involve prayer times and naming ceremonies as well as football games across the picnic ground.

15 Byrne, Goodall, Cadzow, Place-Making in National Parks; Cadzow, Byrne and Goodall, Waterborne; Goodall, Byrne and Cadzow, Waters of Belonging, Byrne and Goodall 'Placemaking and Trans-Nationalism'; Goodall, 'Memory, Mobility \& the More-Than-Human World'; Goodall, 'Remaking the Places of Belonging'. 
Such gatherings are not often welcomed by older Anglo-Irish residents who have lived on the Georges River. For some, these new picnickers reflect something very different from their 'own' community and many remain troubled by difference. However, others, like Elliot Goodacre, are excited by these innovations and welcome the variety of new foods and customs introduced to the picnic grounds!

Regardless, it is sociality that continues to bring people to the river foreshores, the picnic grounds, the bush or the playing fields as well as onto the river itself, swimming, fishing or just remembering. In a very real way, this represents a continuity with the Anglo-Irish river land crowds at East Hills in the 1950s and at Lime Kiln Bay or Poulton Creek with its bushland in the 1970s. It is, in fact, the victory of those earlier campaigns, which saved the inlets from 'reclamation', that enable these culturally diverse socialities - the unfamiliar picnics, prayer mats and foods - to be experienced now so widely across the riverbanks. This might seem to have been an ambiguous victory to the old campaigners, but it has been a victory nonetheless.

The areas that were 'reclaimed' and turned into playing fields are similarly - ambiguous for those people who might have seen themselves as victors in the battles to bring sport to the area. The open, levelled and ordered playing fields, often neatly ringed with seating and shade trees, become empty for all the time when no sports are being played. For some local people, and particularly for women, these empty spaces are unwelcoming after dark, places of foreboding and threat. The vast emptiness of the sports ground - even with lighting, is no comfort. For others, as Matthew Gandy and Denis Byrne have argued, the reclaimed spaces, along with their ring of bushes and trees, become safe and secluded spaces once again as beats for exploratory sexual assignations, whether heterosexual or homosexual. ${ }^{16}$

And the mangroves? Has their elevation to the status of (almost) 'charismatic species' been sustained? Are they still seen as the endearingly maternal and nurturing species portrayed in the 1970s campaigns?

The river land environment has continued to change, sometimes noticed by humans and sometimes not. While mangroves are threatened by encroaching development in many parts of the world, those on the

16 Gandy, 'Queer Ecology'; Byrne, 'Time on the Waterline'. 
Georges River have continued to expand at the expense of the saltmarsh, making the water-land boundary harder to decipher as well as more challenging and - for some - more malevolent. At Towra Point, 62 per cent of saltmarsh has been lost, largely due to mangrove encroachment. ${ }^{17}$

How humans have responded - or even whether they have recognised such changes - remains varied and unresolved. In some parts of the estuary, mangroves have also encroached on former seagrass beds as siltation has raised the riverbed above the range of seagrasses, particularly Zostera capricorni. Perhaps even more significant has been the smothering of mangroves, seagrasses and saltmarsh by drifting sand from Towra Point to Pelican Point. These changes have been widely attributed to the dredging of Botany Bay from the mid-1970s for the construction of airport runways into the bay and Port Botany. Such dredging is claimed to direct significantly more storm wave energy entering from the Tasman Sea to the vulnerable south side of the bay than it had faced prior to the dredging. ${ }^{18}$ How such changes might have expanded or reduced the possibilities for sociality are a question for a later study.

There has been a new recognition of the interests of Aboriginal people over the marine protected area at Towra Point. The promontory includes Pelican Point, William Rowley's birthplace and the home of other Aboriginal families throughout the nineteenth century who lived and fished in the area. Rowley was one who, before he moved to Salt Pan Creek, had been employed by Thomas Holt when he first attempted to set up oyster leases in the shallow waters around Weeney Bay on the eastern side of the Towra promontory.

In the early years of the twenty-first century an unprecedented collaboration between the New South Wales National Parks and Wildlife Service (NPWS) and the Aboriginal communities of the area led to the establishment of the 'Towra Team'. This was a group of 10 young Aboriginal conservation trainees from the La Perouse community, the youngest being 15 with most in their 20s, supported by two older Aboriginal mentors. The whole group was led by Dean Kelly, born in 1967 into the La Perouse community and later employed by NPWS as a community liaison officer. Aiming to distribute opportunities evenly

17 Kelleway et al., 'Seventy Years of Continuous Encroachment'; DECCW, Towra Point Nature Reserve, 81.

18 DECCW, Towra Point Nature Reserve, 57; Laurie Derwent, pers. comm. 
across the Aboriginal community, Kelly selected participants from all the families in the La Perouse area. Each of these young people was chosen because of their interest in learning and the responsibilities for country that the job offered. Kelly pointed out that they had become separated from an active involvement with the land:

These kids are very urban, their environment is [made of] concrete. A lot of them had lost that connection to country and bushland, even though it was so close. They were pretty much disconnected from it and distracted by the bright lights that the city hosts.

Their roles as trainees, however, had allowed them not only to learn more about their country and its history, but also to bring home the remains of their people that had been held in museums for decades. Kelly continued:

The other thing is, within the same area, and only a couple of hundred meters or so from where the birds' nest, we've returned in the last five years approximately 70 Aboriginal remains that came back from the Museums, as part of the Sydney Metropolitan repatriation program ... So there you are, there's another special area there that's very deeply [important] to the Aboriginal community. ${ }^{19}$

More recently still, a team of young Aboriginal people joined the Riverkeeper program in the Georges River Council, incorporating the old Hurstville and Kogarah councils. The program drew the ecological knowledge of the river together with the cultural interests of its diverse riverside communities. ${ }^{20}$ Many of the actors in the Georges River campaigns - from George Jacobsen to the activists trying to save Lime Kiln Bay, Poulton Creek and Towra Point - referred to their goal of honouring the approaches of Indigenous people on the river: hunting, fishing and harvesting only for food, not sport; taking only what they needed to survive, not to accumulate or for competitive show. Yet, until recently, none of those campaigners have taken the step of contacting the many Aboriginal people who survived along the river or who lived at $\mathrm{La}$ Perouse. An imagined vision of what was understood to be tradition was always present, but it was not one that led to real alliances.

19 These quotations all arise from Dean Kelly's paper and later discussion on the Towra initiative, recorded at the Cities Nature Justice symposium at University of Technology Sydney, 10 December 2008. 20 Cavanaugh, 'The Aboriginal Riverkeeper Team'. This program functioned from 2014 to 2017 with government funding. The Indigenous team are now part of the NPWS management of Towra Point. 


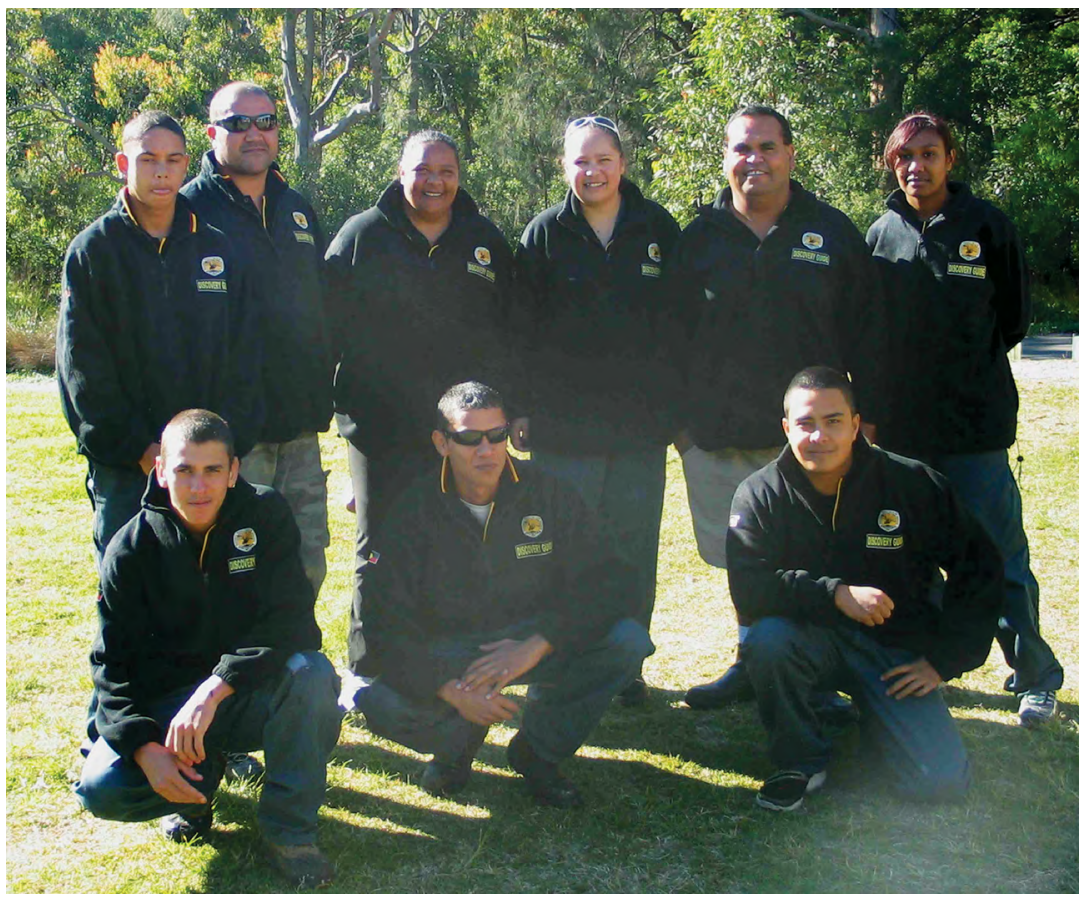

Figure 15.3: The Towra team in 2005.

These young Aboriginal trainees looked after the Towra Point Marine Conservation area while they were in training as rangers with what was then called the Department of Environment and Conservation. Source: Goodall and Cadzow, Rivers and Resilience.

For the campaigners in the period on which this book has focused (1945-80), and for the council officers and representatives, the lines of communication and the memories across time to earlier campaigns were very weak. While some political parties allowed memories of early conflicts to be transmitted, there were a disturbing number of situations in which almost no memories or documents had survived from earlier campaigners, even from those who had been active only a few years before. This remains true today; there are few who remember this period of intense activity along the Georges River when so many people tried to save its waters and bays from reclamation.

This makes activist Dave Koffel's extraordinary personal archive about Lime Kiln Bay, Esme Clisby's visual archive of East Hills Park, Alexandra Knight's collection of the papers and slides of the Save Poulton Park Campaign and Andrew Molloy's tireless local history work about Padstow, East Hills and Milperra all the more important. The stories of these local 
suburban campaigns to save damaged river lands - the campaigners' compromised, polluted but lived environments - have become lost amid the more glamorous and higher profile campaigns for supposedly 'pristine' and remote 'wilderness'. These suburban environmental campaigns need to have their stories recognised and celebrated.

\section{The River I Learned about ...}

This book has been about the river that I came to know as I listened to the people who had taken part in these campaigns. Its pages record many of the conversations I have had as I learned. This was my river, but it was a river I had failed to notice when I had the chance, a river I had missed because I left too soon.

I still have conflicted feelings about mangroves, but I understand better where my concerns came from, and my responses are far more nuanced now. I see more than those strategic campaign images of maternal and nurturing mangroves. I have learned from the many people I have talked with who have shared their warm and affectionate memories of the river and its mangroves.

There will be other ways to look at each of the campaigns I have considered on the estuary and, indeed, there will have been other campaigns that I did not consider at all.

But it has not just been me who has failed to notice this river. In fact, this whole stretch of the estuary, from Milperra to Towra Point, from 1945 to 1980 has been invisible in histories of the environmental movement, of urban heritage campaigns and of social activism. It has been too polluted, too damaged, too compromised, too 'suburban' to be noticed.

So, despite its limits and omissions, this book might open some doors into the dynamism and tenacity of the living beings - human, plant and animal - who all belong to this changing river. 


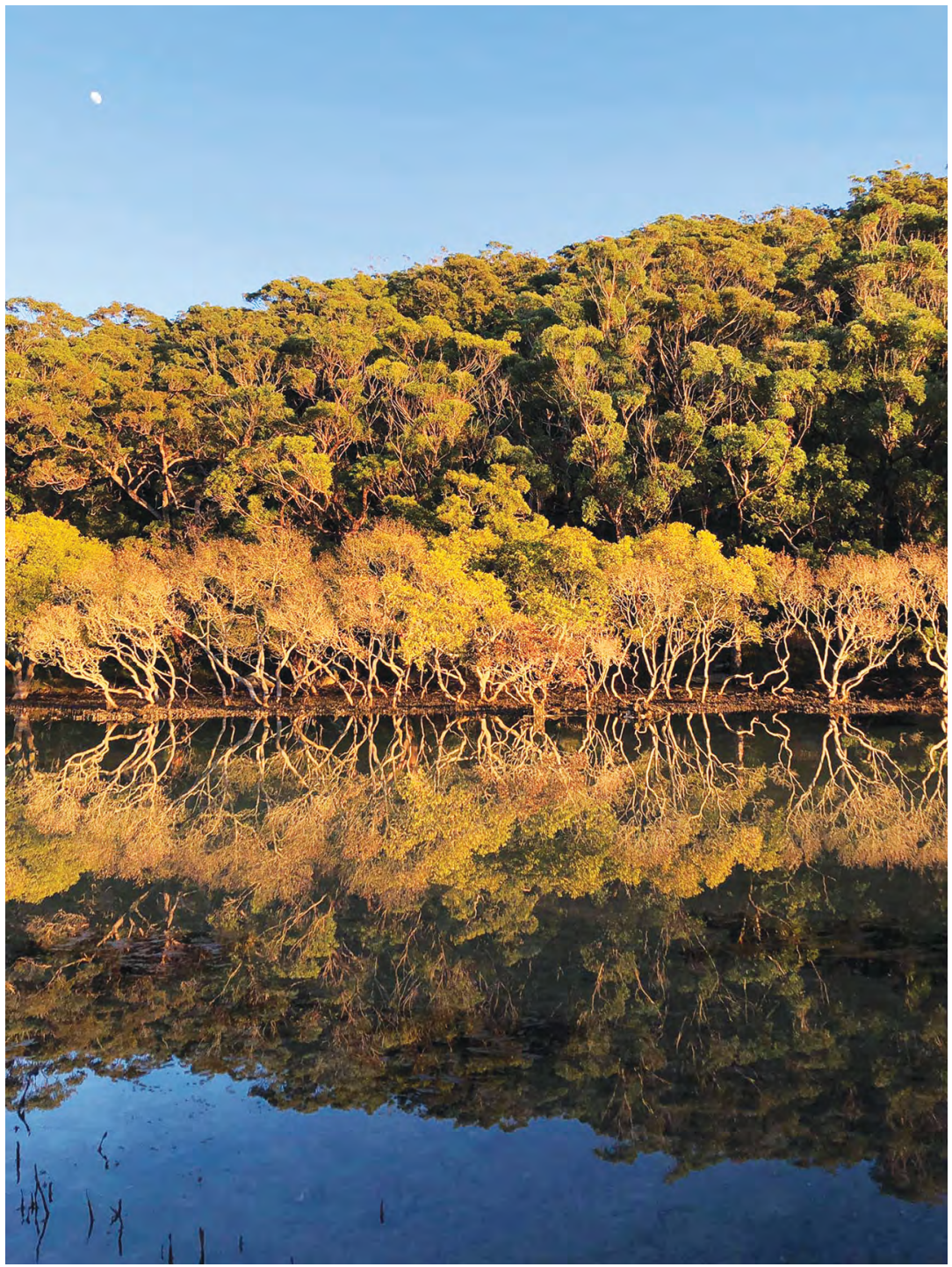

Figure 15.4: Mangrove sunrise, Cabbage Tree Bay.

Taken at Port Hacking, just south of Botany Bay. The moon is visible in this dawn photo. Courtesy of the photographer and ecologist William Gladstone, more of whose photographs can be found on Instagram @williamgladstonephotography. 
This text is taken from Georges River Blues: Swamps, Mangroves and Resident Action, 1945-1980, by Heather Goodall, published 2022, The Australian National University, Canberra, Australia.

doi.org/10.22459/GRB.2021.15 